\title{
Linguistic Impoliteness in The Sociopragmatic Perspective
}

\author{
R. Kunjana Rahardi \\ Sanata Dharma University Yogyakarta \\ E-mail: kunjana@usd.ac.id
}

\begin{abstract}
The discrepancy of the study of linguistic politeness and impoliteness phenonema has been pronounced in the pragmatic study. However, up to this day the study of linguistic impoliteness, particularly based on culture-specific backgrounds has not been done. This research discusses the pragmatic manifestations of linguistic impoliteness. Through this research, a detailed description of how the manifestations and intentions of the linguistic impoliteness markers would be obtained. The data was gathered by using listening and speaking methods in linguistics. The data gathered through the basic and advanced listening and speaking methods was analyzed by using the equivalence method, particularly the extra-lingual equivalence. The research results showed that the pragmatic impoliteness was classified into five categories, namely (1) face-aggravating, (2) face-loss, (3) faceplaying, (4) face-threatening, (5) deliberate ignorance. Each category of the linguistic impoliteness was described in details in its impoliteness subcategories, each was determined by its pragmatic meanings and intentions.
\end{abstract}

Keywords: linguistic impoliteness, impoliteness category, impoliteness phenomena, impoliteness markers

\section{INTRODUCTION}

The study of linguistic impoliteness phenomena has been widely conducted. Miriam A. Locher (2008) recorded that after Bruce Fraser (1994) explained four approaches in linguistic politeness (Locher, 2008), the study of linguistic politeness has flourished immensely. The study of linguistic politeness has been done in Indonesia. The facts can be verified in Rahardi, 2009, Nadar (2009), and in Pranowo (2009). The abundant research results, scientific papers, and scientific journal articles on linguistic politeness - and the similar results in local vernaculars, have been listed in the sociolinguistic politeness index, even for the local vernaculars, or in Rahardi it is referred to as sociopragmatic politeness.

A totally different facts occur in the study of impoliteness. As far as the researcher's concern, referring to Locher et al. (2008), the study of linguistic impoliteness was recorded in Culpeper (1996, 1998), Bousfield (2008), Terkourafi (2008), and Locher (2008). The domain being investigated was limited to the political domain and workplace domain. As of the writing of this paper, the facts described the circumstances eight years ago. In Indonesia, one must admit that the study of linguistic impoliteness is still scarce. In the future, the study of new pragmatic phenomenon must always be done deeply and extensively. The main purpose is to avoid discrepancy between the study of politeness phenomena and the study of impoliteness phenomena as asserted by Locher (2008), 'enormous imbalance exists between academic interests in politeness phenomena as opposed to impoliteness phenomena'.

This research at least can be seen as the 
concrete attitude to respond to the imbalance in the study of two great pragmatic phenomena. This research of linguistic impoliteness is limited to three main domains, namely the education domain, family domain, and religion domain. The limitation to these three domains is to consider that a study on several domains at the same time may affect the depth of analysis and the quality of the findings. Two dimensions of impoliteness will be described in this research, namely the dimensions of manifestation and the dimensions of intentions. Both are interrelated and inseparable.

\section{LITERATURE REVIEW}

According to Miriam A. Locher (2008), linguistic impoliteness is defined as 'behavior that is face-aggravating in a particular context.' The impoliteness refers to face-aggravating behaviors. Such behaviors are more than face-threatening behaviors as defined by Leech (1983), Brown and Levinson (1987), or the concept of face described by Erving Goffman (Rahardi, 2009). Another interpretation is that the action is not merely faceaggravating, but also face-playing actions.

In Bousfield (2008), impoliteness is defined as the issuing of intentionally gratuitous and conflictive face-threatening acts (FTAs) that are purposefully perfomed. Bousfield emphasized on the notion of gratuitous and conflictive. Hence, when someone's action is considered facethreatening, the threat is done gratuitously, which in turn will ensue conflicts, or even dispute. When the action is done purposefully, the linguistic action must be seen as the impoliteness reality.

Culpeper (2008) defines impoliteness as follows: impoliteness, as I would define it, involves communicative behavior intending to cause the face loss of a target or perceived by the target to be so. He emphasizes on the face-loss fact. Thus, impoliteness is a communicative action which is constituted intentionally to cause someone to lose face completely or at least 'to feel' face-loss.

Terkourafi (2008) defines impoliteness as in impoliteness occurs when the expression used is not conventionalized relative to the context of occurrence; it threatens the addressee's face but no face-threatening intention is attributed to the speaker by the hearer. So, the linguistic action is considered impolite when the addressee feels face- threatened and the speaker does not receive a facethreatening action from the addressee in return.

Further, Locher and Watts (2008) view that impolite actions are negatively-marked behaviors. These behaviors are marked negative because they violate the standard social norms in the community. Since the culture is embedded in the society, impolite behaviors violate the cultural norms as well.

\section{RESEARCH METHODS}

The research data was gathered by employing the listening method, both listening with conversation involvement technique and free listening with conversation involvement technique. The data analysis was done contextually, by constituting contexts in interpreting the data which have been identified, classified, and typified. According to the type of data, the contexts being employed in this research are the pragmatic and linguistic contexts. By applying two types of contexts in the data analysis, the description of impoliteness manifestations can be carried out well. The manifestations of the research data are in the form of utterances obtained naturally in the domains previously determined in which the impolite intention is inherent in the linguistic forms.

The research data are gathered by employing the listening method, namely by listening to the direct natural utterance. The technique used to implement the listening method is note-taking and recording techniques. From the notes and records, the ready-made research data are obtained. The research data are also gained by providing stimulus utterances as prompts. The prompting technique is equipped with well-prepared open and secretly hidden note-taking and recording.

The data analysis is done contextually, namely by employing the contextual dimensions in interpreting the identified, classified, and typified data. The contexts being employed in this research are not the sociolinguistic dimensions as stated by Dell Hymes (1972), which have been widely used in the sociolinguistic research, but the pragmatic contexts as stated in Rahardi (2015). The essence of pragmatic contexts is a set of assumptions, both personal and communal. The speaker's intention takes into account the set of assumptions (Rahardi, 2015; Rahardi et al. 2016). 
Contexts in sociolinguistics must be distinguished from the pragmatic contexts. Sociolinguistic context is useful to describe the language varieties, while the pragmatic context is meant to describe the speaker's meanings. Leech (1983) asserts that the findings in the pragmatic study is not a sentence instance but a sentence token. To understand a sentence token absolutely needs contexts because a set of assumptions is inherent in the contexts (Rahardi, 2015; Rahardi et al., 2016).

\section{FINDINGS AND DISCUSSIONS}

The result of the analysis is summarized as follows. There are five categories of linguistic impoliteness in the education, family, and religion domains, namely (1) gratuitous linguistic impoliteness, (2) face-playing linguistic impoliteness, (3) faceaggravating linguistic impoliteness, (4) facethreatening linguistic impoliteness, (5) face-loss linguistic impoliteness.

As repeatedly mentioned, language rules which were based on the data of the European languages, will not apply exactly the same when the linguistic data are changed into Oriental languages, which inevitably have different structures, patterns, and social and cultural relevance. Further, in the implementation of linguistic impoliteness research, the Western theories are not automatically used as the analytical tool, but as the frame of reference only.

Such treatment to the theories leads to subcategories of intentions of various linguistic impoliteness, and one linguistic impoliteness category is above the other linguistic impoliteness category. In great details, the various types of pragmatic intention of impoliteness in each category will be presented as follows.

Linguistic impoliteness which belongs to the category of deliberate ignorance is elaborated into several impoliteness intentions, namely (1) pretense, (2) association, (3) cynicism, (4) arrogance, (5) pleaonasm, (6) puns, (7) condescending, (7) teasing, (8) exclamation, (9) humor, (10) insinuation, and (11) insult. The elaboration of the impoliteness intentions in the category of deliberate ignorance is the most dominant compared to four other linguistic impoliteness categories.
This indicates that our society - which is classified into three domains in this research- are categorized as the kind of people who tend to act gratuitously and create linguistic impoliteness. Such ignorant behaviors are closely connected to the Indonesian people's fondness to crack jokes and play practical jokes with friends.

In the real utterance, excessively bad humor may cause impoliteness. Apparently, it has become the main reason why the linguistic impoliteness in the category of deliberate ignorance is quite dominant in the Indonesian communities.

The following utterances are categorized as the deliberate ignorance.

\section{$\mathrm{X}$ : This girl is getting married soon (Ini bentar lagi nikah.) \\ Y: Oh, no, no, Sir. I am not. I haven't even graduated junior high school. How can I get married? (Weh, pak, nggak yo. Mosok lagi lulus SMP nikah).}

\section{Context of Utterance:}

The conversation took place in front of the administration room of a junior high school, on May 3, 2013. The speaker was a 45-yearold male employee, and the addressee was a 16-year-old male student. The speaker was having a conversation with the addressee during school recess. The speaker knew that the addressee was soon graduating from the junior high school. The speaker was making a joke.

Another excerpt of utterance shows a clearer example.

$\mathrm{X}$ : Are you a teacher or a clairfoyant? Why are you trying to guess the student's future? (Ini guru atau penerawang, siswa kok ditrawang-trawang).

Y: I am just trying to verify whether the money is real or counterfeit by guessing it.

(saya sedang menjelaskan mata uang, Bu).

\section{Context of Utterance:}

The conversation took place on March 27, 
2013 at 11.57, when the class was deeply engrossed in the teaching learning of BIPA (Teaching Indonesian as a Foreign Language). The speaker was a 36-year-old teacher and the addressee was a 22-year-old student. The purpose of the utterance was that the speaker informed the addressee. The utterance was spoken when the speaker assessed the addressee's teaching performance.

The second type of impoliteness was in the category of face-playing. This type of impoliteness can be elaborated into several intentions, namely (1) face-playing through annoying behaviors, (2) face-playing through confusing behaviors, (3) face-playing through mockery, (4) face-playing through insinuation, (5) face-playing through cynicism, (6) face-playing through terse remark, and (7) face-playing through demeaning behaviors.

The purpose of face-playing is proven to be predominantly absent to manifest the fact of impoliteness. This might be caused by the society's view which dislikes the face-playong in conversing. Faceplaying will cause the addressee to feel embarrassed for being played by the speaker. In respect to the concept of "face", face-playing behaviors will obviously cause people to feel embarrassed for having their privacy disturbed.

The Javanese people, for example, will be very cautious in playing someone else's face in such ways. The Javanese people have the philosophy that if you don't want your face being played, do not play other people's face. This philosophy inspires people to be respectful of others and prevents them from playing the addressees' face.

The following excerpt will clarify the point.

X: Move over there! (Kamu pindah sana!)

Y: What do you mean? I belong to group 3 as well!

(Lha piye to, aku kelompok 3 kok! Bagaimana sih, saya kelompok tiga kok!)

\section{The Context of Utterance:}

The conversation took place in the classroom of a school, on May 1, 2013. The speaker was a 25-year-old female teacher. The addressee was the 16-year-old tenth-grade male senior high school student. The speaker knew that the addressee was supposed to be in Group 3, but the addressee was in Group 5. The speaker requests the speaker to move to the actual group he belonged to.

The following excerpt must be considered to clarify this.

\begin{abstract}
$\mathrm{X}$ : Man, you'd better smack that guy!
Lek diantil wae kui! (Segera dihajar/dipukul saja)

Y: I'd better.

Ho'o yo?

\section{Context of Utterance:}

The conversation took place in front of the classroom of a senior high school on May 1, 2013. The speaker was a17-yearold eleventh-grade male senior high school student. The addressee was also a 17-year-old eleventh grade male SHS student. The speaker requested the addressee to smack his annoying friend for always refusing his cry for help.
\end{abstract}

Further, face-aggravating impoliteness can be elaborated into, (1) face-aggravating through insinuation, (2) face-aggravating through criticism, (3) face-aggravating through swear words, (4) face-aggravating through association, and (5) faceaggravating insult by means of acronym.

Bullying and aggravating others are not an honorable action. Face-aggravating behaviors are not done by the speakers in the community because they know that bullying can bring bad impact on the personal relationship between one person and the other. The negative impact of face-aggravating action is more fatal than face-playing actions as the manifestation of linguistic impoliteness.

This is one of the underlying reasons why the impoliteness categories in the form of faceaggravating were not found in this study. In other words, it can be confirmed that face-aggravating action is the manifestation of the Indonesian people's linguistic impoliteness, although this form 
is not the most dominant form.

The following excerpt shows the example of face-aggravating to be considered further.

X: I'd like to ask a question (Aku mau tanya). Y: What is it, Shorty? (Apa, Pendek?)

\section{Context of Utterance:}

The utterance took place at the basket ball field in a school during the Sports class. It was May 3, 2013 at 10.30 a.m. The speaker was a 14-year-old female student. The addressee was also a 14-year-old female student. The purpose of the utterance was that the speaker responded to the question asked by the addressee, who was physically shorter than the speakaer. The utterance was spoken when the speaker was calling the addressee when she was playing basket ball. The basket ball court was very crowded.

The following excerpt is expected to elaborate the issue better.

$\mathrm{X}$ : Look at your hair! Is it proper, to have a hair like that?

"Rambutmu pantes, seperti itu?" (pointing at the student's haircut which did not conform to the norms for a teacher candidate)

Y: Hehehehe.....no, Ma'am. (Hehehe.. iyaa buk).

\section{Context of Utterance:}

The utterance took place in a university classroom, on March 27, 2013. The speaker was a female 36-year-old lecturer. The addressee was a 22 -year-old male student. The speaker in this context saw that the addressee had a new haircut. However, the new haircut was not proper for a teacher candidate. In the speaker's opinion, such haircut was not a proper haircut for a teacher candidate.

Face-threatening impoliteness can be elaborated into the following intention categories: (1) face-threatening through intimidating, (2) face-threatening through leaving no options, (3) face-threatening through cornering, (4) facethreatening through imposing, (5) face-threatening through forcing, (6) face-threatening through condescending, and (7) face-threatening through warning.

Threatening someone's face, both negative face and positive face, is not an honorable deed. Someone's face, wherever it is, must always be saved by the self-image owner. Thus, threat against someone's face may cause him/her uncomfortable. It can be said that his/her self-image is disturbed when her/his face is threatened. In addition, her/his privacy, freedom and autonomy must be perturbed as well.

In the previous research, the facethreatening sub-category of impoliteness did not occur frequently. Hence, it is concluded that the Indonesian people do not like threatening other people's face. Face-threatening category of linguistic impoliteness was present in the conversation, but it must be hammered down again that its occurrence is not significant.

The excerpt of the following conversation to clarify the point.

$\mathrm{X}$ : This Lesson Plan was designed without consulting. So, if it fails miserably, I have nothing to say.

(Ini, RPP tanpa konsultasi, jadi nanti kalau hancur lebur, saya tidak tahu).

Y: Hehe..

\section{Context of Utterance:}

This conversation took place on March 27, 2013 in a university. The speaker in this context was a 36-year-old female lecturer. The addressee was a 22-year-old male student. When the addressee conducted teaching practice, he did not understand his own learning materials because he did not consult the Lesson Plan with his supervisor. As a consequence, the speaker was upset by the addressee's ignorant behavior.

The following excerpt elaborates the linguistic impoliteness category. 
$\mathrm{X}$ : If I go to the back of the room, I will know who are playing with the cellphone.

(Nah, kalau sampai belakang, saya tahu siapa yang mainan $H P$ ).

Y: (Surprised)

$\mathrm{X}$ : Yes.... And you try to hide it under the table. (Haiyaaa ... terus disembunyiin to).

Y: Oh, my Goodness, no, ma'am, I was turning off my cellphone.

(Ya ampun, nggak, saya mau mematikan HP kok).

\section{Context of Utterance:}

The utterance took place on April 29, 2013 in a university seminar room. The speaker was a 35 -year-old female employee. The addressee was a 21-year-old male student.

The face-loss impoliteness category can be elaborated as follows: (1) losing face through strong words, (2) losing face through rude words, (3) face-loss through insult, (4) face-loss through mockery, (5) face-loss through association, (6) face-loss through condescending attitude, (7) face-loss through puns, and (8) face-loss through insinuation.

Losing face in the Javanese culture is called 'ngilangke rai' phenomenon. Someone whose face has lost will lose her/his self-image in the presence of others. Although the face-loss impoliteness is not the sub-category with many pragmatic meanings, face-loss linguistic impoliteness occurs quite frequently in Indonesia.

The following utterance is related with the linguistic impoliteness of face-loss category.

$\mathrm{X}$ : "So, how much is the dog kennel?"

"Piye kandhang kirikke regane pira?"

Y: "Rp 500,000.00"

X: "You bastard! Rp. 500,000.00 for this kind of thing?"

"Bajingan ki mosok regane Rp 500.000,00?"

\section{Context of Utterance:}

This conversation took place in a school on Thursday, April 25, 2013, at 07.00 a.m.
The speaker and addressee were both male students. The purpose of the conversation is the speaker's response to the addressee. During a class discussion, the speaker and addressee were engaged in a casual discussion. They were chatting about the price of a dog kennel. The speaker asked the addressee the price of the dog kennel they wanted to buy. When the addressee told him the price, the speaker could not believe what he heard.

The following excerpt can be considered to clarify the linguistic impoliteness.

$\mathrm{X}$ : The way you write is heavily influenced by the Javanese language!

(Kamu itu cara nulisnya terpengaruh sama konsep bahasa Jawa!)

Y: Oh, really, Ma'am? Gosh!!

(Oh, iya ya buk? Ya ampuuunnnn...)

\section{Context of Utterance:}

The utterance took place in a university classroom on March 27, 2013. The speaker was a 36-year-old female lecturer. The addressee was a 21-year-old female student. The speaker assessed the addressee's learning result. The speaker saw that the addressee used concepts which were influenced by the Javanese concepts.

The research on linguistic impoliteness in the education, family, and religious domains and its significance in the following areas: (1) one of the concrete efforts to anticipate the scarcity in the pragmatic study in the field of linguistics; (2) one of the concrete efforts to stimulate the linguistic impoliteness as one of the new pragmatic phenomena; (3) the new pragmatic research on linguistic impoliteness involving communities from various domains; (4) complete and comprehensive new findings in terms of forms, meanings, and motives of linguistic impoliteness. 


\section{CONCLUSION}

Briefly, the conclusion of the linguistic impoliteness manifestations is presented as follows.

(a) Deliberate ignorance is classified into: (1) pretense, (2) association, (3) cynicism, (4) arrogance, (5) pleonasm, (6) puns, (7) condescending manner, (8) teasing, (9) exclamation, gratuitousness using (19) humor, (11) insinuation, and (11) insult.

(b) Face-playing impoliteness category can be classified into: (1) annoying behaviors, (2) confusing behaviors, (3) mockery, (4) association, (5) cynicism, (6) terse remark, and (7) demeaning behaviors.

(c) Face-aggravating linguistic impoliteness can be classified into: (1) insinuation, (2) mockery, (3) swear words, (4) association, and (5) by means of acronym.

(d) Face-threatening linguistic impoliteness can be elaborated as follows: (1) intimidating, (2) leaving no options, (3) cornering, (4) imposing, (5) forcing, (6) condescending, and (7) warning.

(e) The face-loss linguistic impoliteness can be elaborated as follows: (1) strong words, (2) rude words, (3) insult, (4) mockery, (5) association, (6) condescending attitude, (7) puns, and (8) insinuation.

\section{REFERENCES}

Allan, Keith (1986). Linguistic Meaning. New York: Routledge \& Kegan Paul Inc.

Blum-Kulka, Shoshana (1987). Indirectness and politeness in requests: Same or different? Journal of Pragmatics. 11, 131-146.

Grice, H.P. (1975). Logic and Conversation, Syntax and Semantic, Speech Act, 3, New York: Academic Press.

Grundy, Peter (2000). Doing Pracmatics. London: Arnold.

Leech, Geoffrey N. (1983). Principles of Pragmatics. London: Longman.

Levinson, Stephen C. (1983). Pragmatics. London: Cambridge University Press.

Mahsun (2005). Metode Penulisan Bahasa: Tahapan Strategi, metode, dan tekniknya. Jakarta: Rajawali Pers.

Mey, Jacob L. (1994). Pragmatics, An Introduction Massachusetts: Basil Blackwell Inc.
Morris, Charles W (1938). 'Foundations of the theory of Signs', in O. Neurah, R. Carnap dan C. Morris (Eds.) International Encyclopedia of United Science. Chicago: University of chacago Press.

Nadar, F.X. (2009). Pragmatik dan Penelitian Pragmatik. Yogyakarta. Graha Ilmu.

Parker, Frank (1986). Linguistics for Non Linguists. London: Taylor and Francis Ltd.

Rahardi, Kunjana (2004). Berkenalan dengan Ilmu Bahasa Pragmatik. Malang: Dioma

Rahardi, Kunjana (2006). Pragmatik: KesantunanImperatif Bahasa Indonesia. Jakarta: Erlangga.

Rahardi, Kunjana (2009). Sosiopragmatik. Jakarta: Erlangga.

Sperber, Dan dan Deirde Wilson (1986). Relevance: Communication and Cognition. Oxford: Basil Blackwell Ltd.

Stalnaker, R.C. (1973). 'Pragmatic Presupposition'. In Munitz, M.K. \& D.K.

Unger (Eds.) Semantics and Philosophy. New York: New York University Press.

Thomas, Jenny (1983). 'Cross-cultural Pragmatics Failure'. Applied Linguistics, 4, 2. PP. 91112

Verschueren, Jeff (1999). Understanding Pragmatics. London: Arnold.

Wierzbicka, Anna (1991). Cross-Cultural Pragmatics, The Semantics of Human Interaction. Berlin: Walter de Gruyter. 